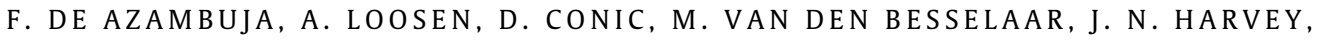

T. N. PARAC-VOGT* (KU LEUVEN, BELGIUM)

En Route to a Heterogeneous Catalytic Direct Peptide Bond Formation by Zr-Based Metal-Organic Framework Catalysts

ACS Catal. 2021, 11, 7647-7658, DOI: 10.1021/acscatal.1c01782.

\title{
Zirconium Metal-Organic Framework Catalyzed Direct Amide-Bond Formation
}
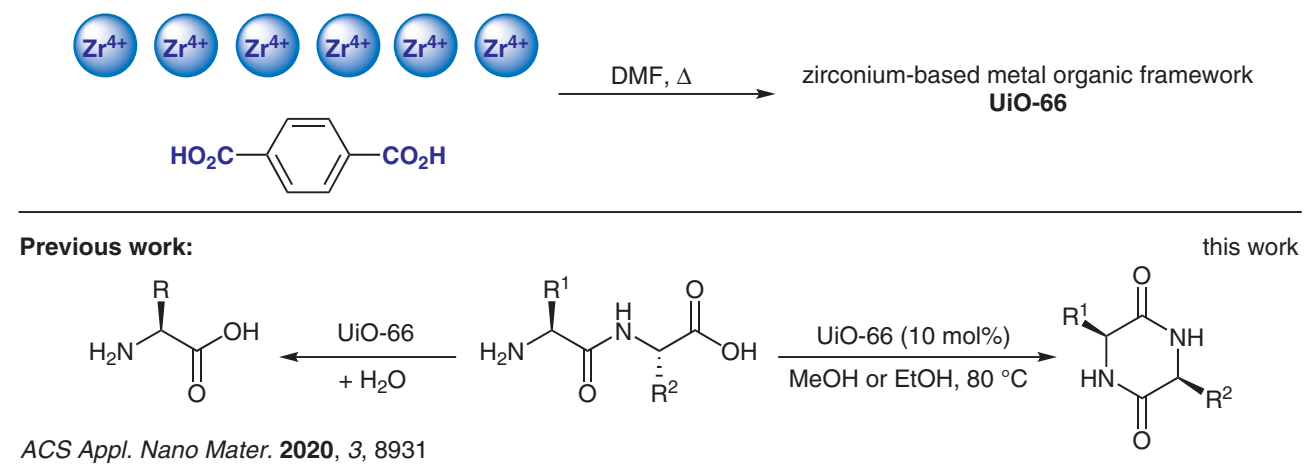<smiles>C[C@H]1NC(=O)CNC1=O</smiles>

$87 \%$ yield (from Ala-Gly) $96 \%$ yield (from Gly-Ala)<smiles>C[C@H]1NC(=O)[C@@H](C)NC1=O</smiles>

$18 \%$ yield<smiles>O=C1CNC(=O)C(Cc2ccccc2)N1</smiles>

$88 \%$ yield (from Gly-Phe) $\quad 91 \%$ yield (from Gly-Ser)<smiles>CC(C)C[C@@H]1NC(=O)CNC1=O</smiles>

$>99 \%$ yield (from Gly-Leu)<smiles>O=C1NCC(=O)N2CCCC12</smiles>

$88 \%$ yield (from Pro-Gly) $92 \%$ yield (from Gly-Pro)<smiles>C[C@@H]1NC(=O)[C@H](Cc2c[nH]cn2)NC1=O</smiles>

$74 \%$ yield (from Gly-His)<smiles>O=C1CNC(=O)[C@H](Cc2c[nH]c3ccccc23)N1</smiles>

$81 \%$ yield (from Gly-Trp)<smiles>COSCCC1NC(=O)CNC1=O</smiles>

$>99 \%$ yield (from Gly-Met)

Catalytic direct amidation:

$\mathrm{PhCH}_{2} \mathrm{CO}_{2} \mathrm{H}+\mathrm{PhCH}_{2} \mathrm{NH}_{2}$

$\underset{3 \AA \text { UiO-66 }(10 \mathrm{~mol} \%)}{\stackrel{\text { MS, in } 1,4 \text {-dioxane, } 80^{\circ} \mathrm{C}}{\longrightarrow}}$

$\mathrm{PhCH}_{2}-\underset{\mathrm{C}}{\mathrm{O}}-\underset{\mathrm{H}}{\mathrm{N}}-\mathrm{CH}_{2} \mathrm{Ph}$

$88 \%$ yield $(71 \mathrm{~h})$

Significance: The zirconium-based metal-organic framework UiO-66 promoted the dehydrative cyclization of dipeptides to form dioxopiperazines. Dipeptide molecules were treated with UiO-66 under anhydrous conditions to give the corresponding dioxopiperazines in good to excellent yields without a loss of their homochirality. The UiO-66 catalyst could be reused five times.
Comment: Note that the intermolecular direct amide condensation of phenylacetic acid with benzylamine also took place with UiO-66 catalyst in the presence of $3 \AA$ MS. The authors have previously reported the hydrolysis of dipeptides, a reverse counterpart of the present condensation, in the presence of UiO-66 (ACS Appl. Nano Mater. 2020, 3, 8931).

Key words

zirconium catalysis

metal-organic

framework

peptides

amidation

amide bonds 